Adrian Jasik

Pontifical University of John Paul II in Kraków

\title{
The view of the lower Tiyari village after Badr Khan Bey's campaign in Austen Henry Layard's account $^{1}$
}

\section{Preparations for the journey}

Layard started his journey to Tiyari Mountains on 28 August $1846 .{ }^{2} \mathrm{He}$ headed off together with his two companions, Hormuzd Rassam ${ }^{3}$ and Ibrahim Agha. He was equipped with the Patriarch's letter to the faithful and the letters from the Pasha of Mosul Mehmed Tayyra, recommending him to both the Turkish provincial authorities, all the way to Amadiyah, and to Abdul Samad Bey, the chief of the Kurdish Berwari tribe, whose territory he was supposed to go through.

${ }^{1}$ The following text was written with the help of the full one-volume edition of Nineveh and its Remains, New York 1854. The book is the result of the studies of Austin Henry Layard who spent some time between November 1845 and April 1847 conducting excavations around the ancient city of Nemrod. His notes concern both the difficulties of the search and excavation and also his numerous trips around the region, including the Tiyari Mountains and Yezidi-inhabited Sinjar. There are many descriptions of the everyday life of the Arab tribes living around Mosul and also the everyday life of the main city of the province.

${ }^{2}$ The Assyrian Christians inhabited the area between Persia and Ottoman Turkey, between the lakes of Van and Urmia. In Turkey they were divided into ashirah, the tribes living in the mountains, independent from the Ottoman authorities, paying irregular taxes called rish $d$-shita and whose only leader was the Patriarch. They inhabited the areas of Tiyari and Thuma. One of their characteristics is the fact that although it was prohibited their men carried guns, which were used for defense against predators and enemies. The other group of the Assyrians lived in the lowlands and was called ra'iyyah. They were more submissive to the Ottoman authorities and Kurdish enemies than their brothers from the highlands. See A. Fortescue, The Lesser Eastern Churches, London 1913, p. 123.

${ }^{3}$ During the conflict his brother Hrmuzd Rassam kept asking the British authorities for intervention. He offered shelter to the Assyrian refugees and bought out many children and women from captivity. His engagement was widely described by G. P. Bader. 
Owing to his notes, we can learn about everyday life of the Christian survivors of the slaughter coming back to their homes, about the state of tension caused by the uncertain situation and Kurdish-Christian relationships at that time.

Layard had already had some contact with the Assyrians from the Tiyari Mountains before since he was willing to employ them to work on the archeological excavation site in Nemrod. He claimed they were much stronger and more disciplined than Arab workers. Some of the workers, who later became his hosts, came from Asheeta. At the first stage of his journey he reached Amadiyah, the most northward town of the Mosul Vilayet. Beyond that point power belonged to the independent Kurdish emirs.

On his way Layard made extensive notes concerning the everyday life of Christians and the Kurdish tribes inhabiting that area, such as the Mizuri tribe. During his journey to Amadiya Layard visited the Christian village of Bebozi, situated on the mountainsides, where he gave an example of missionary work done among Christians. The village had become the Uniate one (Chaldean) just before his visit. On the basis of the inhabitants' account, Layard described the way conversion in the region took place. In all likelihood his account is reliable; contrary to the other Protestant writers, there is no aversion towards the institution of the Catholic Church and her head - the Pope. However, his descriptions are not fully free from small cutting remarks aimed at the "papists" like the Catholic missionaries and the Catholic Church herself were labelled. In his description of the Church in the village of Bebozi, he refers to the wall paintings as "terrible yellow and red daubs, depicting the scenes from the saints' lives and the Mother of God with Child Jesus in a nappy." From his account it results that the missionary work of the Chaldean bishop Mutran Jusuf was supported by cooperation with Mahmud Agha, the chief of the Kurdish Mizuri.

\section{The reasons for the conflict}

Layard's journey took place between the time of the two bloodiest Christians' slaughters of 1843 and 1846. The perpetrator of both massacres was Badr Khan Bey, the Kurdish chief of Buhtan, who together with Nurallah, the emir of Hakkari, attacked the mountains with his army consisting of 70,000 soldiers. Even though the mountains had already witnessed bloody scenes of Christian massacres, never before (i.e., from the times of Tamerlan) were they on such a large scale as in those years.

To find the ember of the conflict one should seek in the political situation of Ottoman Turkey, which was being shaped from the beginning of the $19^{\text {th }}$ century when Mahmud II got to power. His policy aimed at centralising power; he also made some changes in administration, including the liquidation of the Janissary units in 1826 . The difficult political situation of the country was also connected 
with the fact that at that time Porta was in open conflict with Muhammad Ali, the Pasha of Egypt, who occupied the whole Palestine and Syria until the year 1840. Constantinople was becoming more and more dependent on the western power.

Taking advantage of the weakness of the Constantinople authorities, Bad Khan Bey, one of the greatest Kurdish leaders of that time, following the example of Muhammad Ali wanted to gain sovereignty at the cost of the other independent Kurdish emirates and to create a homogenous Kurdish emirate. ${ }^{4}$ One of the reasons for the conflict between the emir and Porta was the overt limitation of feudal lords' power, who had been sovereign so far, by the sultan. The emir started an open conflict in the middle of the 1830s. At that time he began to behave like a sovereign - he minted his own coins and his name was mentioned during Friday services. ${ }^{5}$ All those things were attempts to sever the Turkish superiority. So far the coexistence of the Kurds and Christians in the Tiyari Mountains, who were Hakkari's subordinates, ${ }^{6}$ had been unsettled due to the divergence of both communities' interests. The Assyrians, who were included into the millet system under the rule of Patriarch Mar Shimun XVII Oraham, took the Turkish side as they counted on their help in case of some conflict with the Kurds. ${ }^{7}$ There was also an internal conflict among the Assyrians. At that time two rivals of the Patriarch, namely a deacon called Shamasha Hinno and Kasha Jindo, a priest, appeared in the mountains. The division within the community was visible during the first attack against the Assyrians in the Tiyari Mountains, where Badr Khan Bey was supported by the Assyrians from the Takhuma region. The latter, however, were the aim of the Kurdish attacks in the year 1846. The same was in 1843 when the inhabitants of the village of Zawitah, directly neighbouring with Asheeta ${ }^{8}$ did not experience any attacks.

According to Gabriele Yonan's work Lest We Parish. A Forgotten Holocaust. The Extermination of the Christian Assyrians in Turkey and Persia, ${ }^{9}$ the conflict arose due to the decision of the Patriarch himself who, persuaded firstly by the American and later by the British missionaries, terminated his collaboration with

\footnotetext{
${ }^{4}$ It is not fully clear how Badr Khan wanted to create a sovereign Kurdish country. See D. Mc Dowall, A modern history of the Kurds, London-New York 2000, p. 47.

${ }^{5}$ See: J. Joseph, The Modern Assyrians of the Middle East. Encounters with Western Christian missions archeologists and colonial powers, Leiden 2000, p. 72.

${ }^{6}$ In the period preceding the slaughters of 1843 there were some less serious conflicts; however, they never took such a cruel form as at the time described.

${ }^{7}$ During the first slaughter in 1843 the Pasha of Mosul was completely passive. It was the intervention of the powers of the West and the missionaries and especially the British ambassador Sir Stafford Canning that brought some effect. W. Jwaideh, The Kurdish National Movement. Its origin and development, New York 2006, p. 72.

${ }^{8}$ A. H. Layard, Niniveh and its Remains, New York 1853.

${ }^{9}$ The same hypothesis is made by the Eastern Church researcher A. S. Atiya in his work The History of Western Churches, Warsaw 1978, p 244.
} 
the Kurdish emirs, counting on the favour and support of the western powers, especially Great Britain. ${ }^{10}$ The other writers indicate a few sources of the conflict, such as the fanatic piety of Badr Khan Bey (the following reason was also very often mentioned by Layard). They did not, however, choose any of the reasons given as the determining one. ${ }^{11}$

\section{On the way to Amadiya}

After a short visit to the fever-stricken Amadiya, Layard, together with his companions, set out north for Asheeta, the Assyrian village, which was the biggest Christian settlement in that region. To the foot of the Tiyari Mountains Layard was accompanied by the Kurdish units chosen by Abdul Samad Bey. However, because of the tension between the two communities, the Kurds did not decide to accompany the men any farther. From Layard's description we can assume that the way to Asheeta was troublesome. For centuries the narrow and winding road along the mountain range functioned as a shelter for the Christians inhabiting the mountains, which enabled them to defend themselves effectively against the enemy greater in number. In Asheetah he was welcomed by rais Jacob, who was supposedly one of the first Tiyari leaders to be taken by Badr Khan Bey in the summer of 1843.

\section{The picture of the Tiyari villages after Kurdish attack}

The massacres and destruction caused by the Kurds were still visible in the mountains three years later. Most villages Layard saw were depopulated. The fields lay fallow; the irrigation system did not work as there were not enough people to work. In Asheetah, which he visited first, the rubble of houses lay among gardens, partly cut off by the Kurds. Layard said it was visible that every part of the land in the region which was good for farming was cultivated. Along the valley there were terraces of farmlands. Now, however, they were mostly uncultivated. There were shortages of food in the whole region, and Layard and his companions were hosted very poorly. He noticed that up to the region of Takhuma there were no livestock pasturing as they had been taken by the Kurds after the attack. ${ }^{12}$ The only example of a village which avoided the fate

${ }^{10}$ The following decision, the wrong one as it turned out, set the policy of the Patriarch who never again made any deals with the American missionaries. He also looked at their works with an unfavourable eye. In David Trappan Stoddard's letters published in his memoirs Memoire of Rev. David Trappan Stoddard, New York 1858, p. 171, one can see that the Patriarch did not trust the work of the American missionaries.

${ }^{11}$ In spite of the fact that in most cases Layard writes about Alims and Kurdish leaders as fanatic Muslims, he shows respect to the hospitality of the Kurdish villagers.

${ }^{12}$ H. A. Layard. Niniveh and its remains, New York 1853, p. 171. 
of the others was the neighbouring village of Asheeta-Zawitah. It was the only place in the region which was vibrant with life, and it was due to the favour which the village rais had done to Badr Khan Bey.

About 200 families came back to Asheeta. ${ }^{13}$ Layard was surprised to see the agricultural abilities of the Assyrians. All the inhabitants of the village, including the clergymen, were involved in rebuilding the village. Though isolated, the region was self-sufficient, abundant in rice, tobacco and grains, including wheat and barley. Unfortunately, the 1843 attack ruined the Christian peasants. In Asheeta Layard visited the ruins of the mission founded by Ashley Grant in 1842. During the attack it was occupied by Zenal Beg, one of the leaders of Badr Khan Bey, and his 400 warriors. ${ }^{14}$ The mission was situated on the hill; it was isolated but well fortified. In 1846 it was already ruined but earlier it had been a perfect place for defense. Both the Kurds and the Assyrians had a chance to see that. The Assyrians, who could not stand the pressure, attacked the Kurdish garrison but suffered a devastating defeat which resulted in slaughter and devastation of the settlement. In his accounts Layard confirmed the opinion that the building was a thorn in the Kurdish emirs' eye as he saw it as an example of Christian arrogance and disregard. The churches also fell victim to the Kurdish attack. The clergymen and monks were murdered. The Patriarch himself lost three members of his family, including his mother, one of the five brothers and his nephew. ${ }^{15}$ Due to the attack, the lack of priests became a problem. Those who survived were walking from village to village to celebrate the Masses. ${ }^{16}$ Many of the manuscripts, precious for the Assyrians, were lost. They were either destroyed by the Kurds or hidden forever in the mountains by the priests who were dead now. The important thing is that the first buildings which were rebuild were churches. Layard described a church from Asheeta, where there was nothing but a few manuscripts falling apart and a few English pieces of fabric from Manchester. ${ }^{17} \mathrm{He}$ added that the entrance to the church was so low that you could enter it only by bending down. Ainsworth states there were four churches in Asheeta, which can mean that they were completely destroyed as Layard did not mention them. According to Layard, but also to Grant and other writers, the Assyrians, strongly connected with their

${ }^{13}$ Badger states that before the Kurdish attack there were about 2,500 Assyrians in Asheeta. G. P. Bader, The Nestorian and their rituals: with the narrative of a Mission to Mesopotamia and Coordistan in 1842-44, and of a late visit to those countries in 1850: also, researches into the present condition of the Syrian Jacobites, Papal Syrians, and Chaldeans and an inquiry into the religious tenets of the Yezeedees, vol. 1, London 1852, p. 214.

${ }^{14}$ Ibid., p. 276.

${ }^{15}$ D. Wilmshurst, The ecclesiastical organization of the Church of the East, 1318-1913, Livonia 2000, p. 296.

${ }^{16}$ H. A. Layard. Niniveh and its remains, New York 1853, p. 161.

${ }^{17}$ Ibid., p. 158. 
religion, did not want to use the newly rebuilt church before the Patriarch's dedication, and that was some kind of discomfort for the people.

The villages between Asheeta and Lizan were desolated; only few families that survived the massacre decided to return there. In Miniyanish twelve homesteads out of seventy were rebuild. Indirectly from the rais Jacob we find out that 300 people from the settlement lost their lives. In the village of Murghi the survivors rebuilt eight houses.

Before the massacre Lizan, with the bridge over the Great Zab River as its center, had been a big settlement situated in the road hub important to the region; now it was completely destroyed. According to Layard the only place where they could stay for the night was the roof of the church, which had been rebuild as the first element. During the day the inhabitants slept in their orchards but they would move near the river Zab for the night, where they built temporary makeshift beds from grass and branches, which provided some protection against insects. The fact that malik himself suffered the same fate proves how poor their situation was.

In Lizan Layan was taken to the hill where one of the most terrible Christian slaughters had taken place. Three years after the event, he could still see some human remains scattered all over the place. Layard went on his journey right before the next attack of Badr Khan Bey on the Assyrians, which is the reason for his numerous remarks about the tension and fear prevailing among the Christians who waited for future events. He showed a picture of the inhabitants of the mountains who, weakened by the bloody massacres, slowly tried to come back to their normal lives. 